\title{
Impact of Improved Corporate Governance and Regulations on Earnings Management Practices-Analysis of 7 Industries from the Indian National Stock Exchange
}

\author{
Jose Joy Thoppan ${ }^{1}\left(\mathbb{D}\right.$, Robert Jeyakumar Nathan ${ }^{2} \mathbb{C}$ and Vijay Victor ${ }^{3,4, *}$ \\ 1 Saintgits Institute of Management, Kottayam 686532, India; jose.joy@saintgits.org \\ 2 Faculty of Business, Multimedia University, Melaka 75450, Malaysia; robert.jeyakumar@mmu.edu.my \\ 3 Department of Economics, CHRIST (Deemed to Be University), Hosur Road, Bangalore 560029, India \\ 4 College of Business and Economics, University of Johannesburg, P.O. Box 524, \\ Auckland Park 2006, South Africa \\ * Correspondence: vijay.victor@christuniversity.in
}

Citation: Thoppan, Jose Joy, Robert Jeyakumar Nathan, and Vijay Victor. 2021. Impact of Improved Corporate Governance and Regulations on Earnings Management PracticesAnalysis of 7 Industries from the Indian National Stock Exchange. Journal of Risk and Financial Management 14: 454. https:// doi.org/10.3390/jrfm14100454

Academic Editor: Ştefan

Cristian Gherghina

Received: 4 August 2021

Accepted: 7 September 2021

Published: 22 September 2021

Publisher's Note: MDPI stays neutral with regard to jurisdictional claims in published maps and institutional affiliations.

Copyright: (c) 2021 by the authors. Licensee MDPI, Basel, Switzerland. This article is an open access article distributed under the terms and conditions of the Creative Commons Attribution (CC BY) license (https:// creativecommons.org/licenses/by/ $4.0 /)$.

\begin{abstract}
This study investigates discretionary earnings management practices, tracing the changes over the years in selected top performing and highly liquid listed Indian firms. It empirically measures the impact of corporate governance, financial legislation and global reporting standards on the firms' earnings management practices. The study analyses a sample of 712 firm-year data comprising 89 listed Indian companies across 7 different sectoral indices of the National Stock Exchange of India (NSE) over 8 years (2011-2018). The Modified Jones model was used to compute Discretionary Accruals to measure Earnings Management based on data obtained using Bloomberg terminals. Statistical results and plots generated in Stata offer evidence that instances of earnings management have significantly reduced after the enactment of the Companies Act 2013 and the adoption of Indian Accounting standards which are converged with the IFRS. Findings suggest that services firms are engaging in relatively higher levels of earnings management compared to manufacturing firms. This study reveals the positive impact of improved corporate governance, regulation, and enforcement by significantly reducing the levels of earnings management among listed firms in India.
\end{abstract}

Keywords: accounting standards; financial sustainability; Companies Act 2013; corporate governance; discretionary accruals; investment sustainability; Modified Jones model

\section{Introduction}

The aim of every organization is to maximize shareholders' wealth. At the same time, there are several other factors that require organizational balancing acts, including managing analyst expectations and handling agency-principle conflicts etc., which place pressure on companies to return healthy profits continuously. In order to achieve these often-conflicting objectives, companies should ensure that they maintain high standards of corporate governance by not compromising long-term business sustainability for shortterm gains. Škare and Hasić (2016) explain the link between corporate governance, firms' performances, and economic growth. Popescu and Popescu (2019) posit that sustainable finance, corporate social responsibility, and human capital have become critical to evaluate the success and competitive advantage of an organisation and its influence in the marketplace. The firms that are in pursuit of earning profits and quarterly performances should also take into consideration the long-term impact of their activities on the various stakeholders and the economy as a whole through sustainable investments. Dhaoui (2008) shows that managers tend to pursue a non-wealth maximizing behaviour to maximize their own personal utilities at the cost of shareholders' interests. The managers' myopic actions may adversely impact the firms' long-term financial sustainability. There are quite 
a few examples of creative accounting practices that have led to adverse results. Among others, Enron (Stewart 2006), WorldCom, and Anderson Consulting (Brickey 2003) in the US and Satyam Computers and IL\&FS in India can be noted. The events stemming from such practices discourage investors from participating in the markets, thus depriving firms of capital. This disrupts economic cycles and hampers recovery and the free flow of capital (Punniyamoorthy and Thoppan 2012). These instances highlight the fact that such actions affect not only the organization but also the broader economy for a considerable period of time, leading to situations of joblessness and investment-less growth. This can also aggravate market crashes (Kedia and Philippon 2007; Nosratabadi et al. 2020). On the contrary, the right investments that firms make would potentially lead to both financial and non-financial performance outcomes (Nathan et al. 2019).

Earnings management (EM) is the deliberate attempt by managers to misstate a company's earnings in order to mislead stakeholders regarding the economic performance of the company, or to influence certain contractual outcomes (Fisher et al. 2016). Leuz et al. (2003) highlight scenarios where managers can use their reporting discretion to overstate a firm's reported earnings to achieve earnings targets or favourably influence an equity issuance. They can also understate current earnings to establish cookie jar reserves. These reserves are later used to boost earnings and influence reappointments or to cover shortfalls. The common areas where cookie jar reserves are created include sales returns and allowances, debt write-offs, inventory write-downs, warranty costs, pension expenses, and percentage completion of long-term contracts, etc.

Managers indulge in earnings misrepresentation mainly to influence stock prices or to meet internal and external demands for higher earnings, better executive compensation, and career prospects (Dichev et al. 2016; Graham et al. 2005). Suryani et al. (2018) conclude that opportunistic behaviour by managers adversely affects firm performance. Once poor earnings quality is detected, stock price declines and cost of capital increases. The ethically sound companies with good operating performance are adversely affected if the ethically bad firms try to camouflage adverse financial performances (Byun and Roland-Luttecke 2014). Zéman and Lentner (2018) suggest that developing a good accounting system with proper controlling features is required for a going concern. After all, these are the financial statements that potential investors and creditors look for when they are making an investment decision. Companies with better corporate governance standards and transparency norms might lose to pretenders (firms who engage in window dressing) in convincing investors based on dressed-up financial statements. This would affect the long-term performance of the genuine businesses and the economy at large. In short, ethical and compliant businesses serve the larger purpose of meeting the basic goals of a business: efficiency, sustainable growth, and shareholder value.

In order to control the misstating of financial statements, the International Financial Reporting Standards (IFRS) was brought in by the International Accounting Standards Board to provide a common and unambiguous reporting language across international boundaries. The Indian version of the IFRS is the IndAS, which has had a phased rollout in India. In the initial phase, it was made mandatory for large, listed firms that had a net worth of Rs. 5 billion (Approximately USD 68.5 million) to adopt IndAS from the 1st of April 2016. The full and final convergence will be when the insurance firms adopt it in FY 2020. Ipino and Parbonetti (2016) carried out a multi country study involving 37 nations and found evidence indicating fall in levels of accrual-based Earnings Management (EM) after the mandatory adoption of IFRS. They further observed that this decline was more pronounced for companies domiciled in countries with relatively stricter legal enforcement regimes. However, in a recent study by Doukakis (2014), carried out on data from 22 EU nations, it is shown that EM has not declined after the mandatory adoption of IFRS in 2005. A similar study on German firms by Van Tendeloo and Vanstraelen (2005) showed that there was no difference in levels of EM by German firms applying IFRS and those using German accounting standards. Although there are multiple studies documenting the existence of EM in Indian firms and outlining the benefits of IFRS in curtailing earnings 
management globally (Shen and Chih 2005; Sarkar et al. 2008; Rudra and Bhattacharjee 2012; Dayanandan et al. 2016), there is no attempt to study the impact of the adoption of IndAS (the Indian version of IFRS) on Earnings Management.

In this paper, we present evidence of EM in the large listed Indian firms before and after their mandatory adoption of IFRS in April 2016. The study examines the changes in levels of EM over time to see if regulations have varying degree of impact on EM trends across industry groupings. The present study contributes to the literature by examining if regulatory reforms can bring about a reduction in manipulative practices like EM in an emerging market economy like India, which has not been attempted so far. The study also conducts further analysis to test the levels of improvement that regulations can bring in different industry sectors in the Indian context.

The rest of this paper is organized as follows. Section 1 provides (a) a concise theoretical background to EM and (b) an overview of developments in the regulatory and reporting standards which are aimed at curtailing this practice. Section 2 discusses the period of study, data sources, and the methodology. Section 3 provides the empirical results derived through the model. Section 4 discusses results and conclusions to better understand the phenomena, presents the limitation of the present study, and highlights the scope for future work.

\section{Literature Review}

Sustainable business can be referred to as smart business, wherein the management is making optimum and wise utilisation of its available resources without depriving the next generation of their requirements (Steurer et al. 2005). The profitability and growth of companies and the impact of sustainable business practices on financial performance are revealed in the study by López et al. (2007). Khan et al. (2018) observe that when the legal system is weak and corporate governance is underdeveloped, firms exhibit severe agency problems. Larcker et al. (2007) discuss how strict adherence to 14 dimensions of corporate governance contribute to effective organizational outcomes and the productivity of the firm. Baik and Lee (2007) reveal how industry deregulations influence the level of EM in the U.S. airline industry. Liu and Lu (2007) show that higher levels of corporate governance can lower the earnings management in Chinese firms. González and García-Meca (2014) point out that implementation of strict controls and strengthening regulations influence EM negatively.

Lin and Hwang (2010) show that for a business to grow in a stable and sustainable manner it must make optimum utilization of resources. It serves the best interest of all stakeholders that a firm properly discloses its financial and operational performance in a manner that meets global standards and norms. They also show, through a meta-analysis technique, that the quality of audit and standards followed by businesses influence the degree of earnings manipulation. The central point for the study by Cohen et al. (2014) is that management can ensure effective compliance to the ethical and legal standards by strongly adhering to the financial reporting process.

$\mathrm{Du}$ and Shen (2018) show that peer performance positively influences discretionary accruals (DA). Di Meo et al. (2017) studied firms that meet or just beat estimates to show that entrenched managers are less likely to engage in EM than managers who have just taken over as there is less pressure for them to perform every quarter highlighting the agency problem. Lambert and Sponem (2005) emphasize that it is the shareholder pressure that compels the management controllers to manipulate the profits of the organization. Kang and Kim (2012) investigate how weak corporate governance structure can influence EM.

IFRS adoption is expected to control and curb misstating of financial statements by providing a common and unambiguous reporting language across international boundaries. Jeanjean and Stolowy (2008) focus on pre- and post-effects of such implementation. A similar study was conducted by Van Tendeloo and Vanstraelen (2008) to determine whether changes in EM level is influenced by adoption of IFRS in various countries. The 
implementation of the Sarbanes Oxley Act (SOX), also known as the Corporate and Auditing Accountability, Responsibility and Transparency Act, 2002, was effective in bringing down the level of accrual-based EM in the U.S. Park (2019) finds that in firms having CEO duality, the compensation of executives at peer firms have a direct influence on the levels of accrual-based EM. He also establishes that the levels have significantly come down after the passage of SOX. Cohen and Zarowin (2008) have observed that after the passage of SOX, there was a shift from accrual-based earnings management to real earnings management in the United States.

Burgstahler and Dichev (1997) have shown how small firms or ethically weak firms indulging in earnings manipulation shut down growth prospects for large or ethically strong firms. The ethically deviant companies camouflage their earnings numbers, which can be observed from an incidence of more small positive and fewer small negative numbers than expected.

Corporate Governance is a set of systems, processes, and principles. It is self-defined or mandated by law and guides a manager to work in the best interest of the investors, thus governing the agency problem (Larcker et al. 2007). Shen and Chih (2007) found that lower earnings management are observed in companies with effective corporate governance mechanism. Klein (2002) observed that firms which have independent directors in audit committees generally have lower abnormal accruals. This was confirmed in later studies by Rahman and Ali (2006) and Epps and Ismail (2009). Studies by Cheng and Warfield (2005) showed that when managers had higher ownership in firms, such firms showed evidence of lower earnings management

The Companies Act (1956) was the basic framework governing Indian firms. The liberalization and globalization of the Indian economy in 1991 opened up the Indian market to global investors. To ensure orderly functioning of the markets, the Securities and Exchange Board of India (SEBI) was established in 1992. Based on the recommendations of Kumarmangalam Committee on Corporate Governance, Clause 49 of listing agreements was promulgated in 2004, giving firm guidelines on corporate governance, including the quality of financial reporting (Srivastava et al. 2018). In 2009, the Ministry of Corporate Affairs (MCA) issued new Corporate Governance Voluntary Guidelines and Corporate Social Responsibility Voluntary Guidelines.

The International Monetary Fund (2013) Country Report, on assessment of the financial sector in India, observed that issuer compliance on reporting requirements was a major challenge faced by SEBI. Furthermore, it noted that though there is an intent to move towards international standards, the review of financial statements by MCA and oversight of auditors were not effective.

The new Companies Act, 2013, and subsequent amendments removed most deficiencies identified and ushered in a set of well-defined corporate governance norms. In 2011, India announced its intention to converge Indian accounting standards with IFRS, which was formally notified as Ind AS under section 133 of the Companies Act. The revised and improved version of Clause 49 of the listing regulation was introduced by SEBI in 2014 (Srivastava et al. 2018). Voluntary adoption of Ind AS was encouraged from 1 April 2015 and it was made mandatory for listed companies from 1 April 2016. The National Financial Reporting Authority was constituted under section 132 of the Companies Act to establish and enforce accounting and auditing standards and undertake oversight of auditors. Auditing firms are restricted to engaging in non-audit fee-based activities for firms they audit. Furthermore, the stock exchanges as self-regulating organizations (SRO's) and the auditors of the firms are expected to highlight any offence or fraud that come to their notice to the central government.

Callao et al. (2016) provide evidence that stricter accounting rules alone do not solve the problem of earnings manipulation, arguing that strong enforcement is also required. This study attempts to track the consequences of these regulatory changes, the alignment of the Indian Accounting Standards to global standards, the new Companies Act, and the 
setting up of enforcement agencies on the quality of financial reporting from an earnings management perspective.

\section{Materials and Methods}

The data for the study are comprised of annual financial figures of 89 listed companies constituting seven different sectoral indices of the National Stock Exchange (NSE) of India. The firms are selected based on their membership in the seven sectoral indices, their financial data being available, and their membership in the group of firms that have to mandatorily report their financial data according to IndAS from 1 April 2016 onwards. The seven sectoral indices selected for the study include Automobile, FMCG, Information Technology, Media, Metal, Pharmaceutical, and Realty. The other sectoral indices published by NSE, namely banks, PSU banks, private banks, and financial services industry groupings, were not considered for this study owing to their unique practices (Carcello and Nagy 2004), the differences in their accounting practices, the different timeline for when IndAS becomes mandatory, and the additional regulations followed in their financial reporting. Our rationale for taking the 89 firms in this study, which are the most liquid and under the greatest scrutiny from analysts, investors, and regulators alike, was to understand if there is earnings management among the larger more liquid firms and if the practice has been reduced by the recent regulatory changes and supervision.

The quantitative data collected from Bloomberg consists of the following variables: revenue (REV), total assets (TA), total current assets (TCA), gross property plant and equipment (PPE), depreciation and amortization (D\&A), short term receivables (REC), cash and cash equivalents (CCE), current liabilities (TCL), and short-term debt (STD) of identified companies for the period 2010 to 2018. This period is used in the study to see the impact of major regulatory changes introduced in 2013 and improvements introduced in 2016 on the discretionary accruals of firms. The raw data is cleaned to remove discrepancies by dropping observations with missing or unreported values. Data with negative asset values were also dropped from the study. The Modified Jones model was then applied using Stata, the output of which reveals the firm level earnings management data for the above period.

Earnings management is generally difficult to detect. However, it can be safely said that a manipulation of profits implies that accrual has been manipulated. This is because profit differs from cash flow by total accruals. To detect EM, Healy (1985) introduced a discretionary accrual-based model. DeAngelo (1988) improved upon this model, but both these models used total accrual and thus neglected the varying non-discretionary accruals. Goel (2018) used the DeAngelo model to study 25 Indian firms and established that multi-nationality, firm reputation, and leverage influence the levels of accruals. The studies carried out subsequently by Jones (1991); Dechow et al. (1995); Rangan (1998); Teoh et al. (1998); and Teoh et al. (2002) used discretionary accruals as a measure of EM. This is because non-discretionary accruals can normally vary in the course of business or due to the changes in the business environment, but discretionary accruals can be completely controlled by the managers. Jones (1991) believed that the variations of revenue would bring variations in operating capital, causing a change in accruals, and that the depreciations on fixed assets would decrease the accruals. As a modification to the Jones model, Modified Jones Model was established as a more powerful model by Dechow et al. (1995), which is identical to the standard Jones model with the exception that the change in debtors $(\triangle \mathrm{REC})$ is subtracted from changes in revenue $(\triangle \mathrm{REV})$ at the second stage (Equation (4)). This two-stage model is also referred to as the cross-sectional model wherein the result of the first stage is infused into the second equation. All abbreviations are explained in Appendix A. 
The following are the steps of Modified Jones Model:

Step 1: The raw data collected from the Bloomberg database is run on Stata to compute the Total Accruals (TACC). Total Accruals (TACC) are estimated using the following equation:

$$
\mathrm{TACC}_{t}=\Delta C A_{t}-\Delta C a s h-\Delta C L_{t}+\Delta D C L_{t}-D E P_{t}
$$

Step 2: Estimate Modified Jones Model, as defined below: The variables and the TACC value generated from the Equation (1) is provided as input to Equation (2) and run on Stata to extract the regression coefficients, namely $\alpha_{1}, \alpha_{2}$ and $\alpha_{3}$.

$$
\frac{\mathrm{TACC}_{t}}{A_{t-1}}=\alpha_{1} \frac{1}{A_{t-1}}+\alpha_{2} \frac{\left(\Delta R E V_{t}-\Delta R E C_{t}\right)}{A_{t-1}}+\alpha_{3} \frac{P P E_{t}}{A_{t-1}}+\varepsilon_{t}
$$

Step 3: Calculate the discretionary accruals: The regression coefficients obtained from Equation (2) are substituted in the Equation (3) to obtain the non-discretionary accruals (NDACC).

$$
\frac{N D A C C_{t}}{A_{t-1}}=\hat{\alpha}_{1} \frac{1}{A_{t-1}}+\hat{\alpha}_{2} \frac{\left(\Delta R E V_{t}-\Delta R E C_{t}\right)}{A_{t-1}}+\hat{\alpha}_{3} \frac{P P E_{t}}{A_{t-1}}
$$

Step 4: The discretionary accruals is calculated by subtracting the non-discretionary accruals calculated in Equation (3) from the total accruals calculated in Equation (1).

$$
D A C C=T A C C_{t}-N D A C C_{t}
$$

Ronen and Yaari (2008) observed that EM can be due to a manager's accounting choices and policies, which can lead to discrepancies between timing of cash flows and accounting income recognition. Young (1999) tested the robustness to measurement error of 5 models and concluded that the Modified Jones Model is the best suited to measure levels of EM. A study by Moradi et al. (2015) provides evidence that the Modified Jones Model was effective in detecting accrual-based EM and establishing the association between accrual-based EM and managers' bonuses. Dayanandan and Sra (2018) estimate both modified Jones with firm-specific coefficients and found that the Modified Jones Model using firm-specific coefficients is most suited in the Indian context.

\section{Results}

The initial data for the study collected from Bloomberg consisted of 712 firm year records, taken for the period 2011 to 2018, across 89 companies from the seven sectoral indices, namely NIFTY Auto (10 companies), NIFTY FMCG (15 companies), NIFTY IT (10 companies), NIFTY Media (14 companies), NIFTY Metal (15 Companies), NIFTY Pharma (10 companies), and NITY Realty (10 companies) of the National Stock Exchange of India (NSE). The 2010 data collected were used for computing the difference values $(\Delta)$, as required by the model, and so are not included in the calculation. After eliminating 53 records because of missing or unreported values in certain years for certain variables, the final set consisted of 659 firm-year data.

Table 1 presents the summary statistics of the variables used to compute discretionary accruals, consolidated across all sectors and across years. Table 2 highlights the mean values of all variables for all years by the seven sectors individually. Table 3 summarises the year-wise descriptive statistics of all variables for all sectors combined. 
Table 1. Summary Statistics of the variables used in the study (in million rupees).

\begin{tabular}{ccccc}
\hline Variables & Mean & Standard Deviation & Minimum & Maximum \\
\hline REC & $20,959.29$ & $35,037.88$ & 10.16 & 249,430 \\
\hline REV & $192,509.90$ & $355,350.80$ & 170.00 & $2,885,961$ \\
\hline PPE & $133,836.90$ & $301,478.00$ & 42.92 & $1,795,240$ \\
\hline TCA & $114,699.80$ & $187,662.10$ & 145.88 & $1,359,728$ \\
\hline TA & $265,084.80$ & $451,802.20$ & 743.60 & $3,313,505$ \\
\hline TCL & $79,257.24$ & $150,645.70$ & 459.67 & $1,432,195$ \\
\hline STD & $21,825.73$ & $45,957.25$ & 0.00 & 322,450 \\
\hline CCE & $22,809.01$ & $66,592.12$ & 5.75 & 622,360 \\
\hline D\&A & 8014.23 & $18,539.62$ & 12.49 & 215,536 \\
\hline
\end{tabular}

Table 2. Industry wise mean values of the variables (in million rupees).

\begin{tabular}{cccccccc}
\hline \multirow{2}{*}{ Variable } & Auto & FMCG & Media & IT & Pharma & Realty & Metal \\
\cline { 2 - 7 } & $* \mathbf{n}=\mathbf{1 0 4})$ & $\mathbf{( n = 1 1 6 )}$ & $\mathbf{( n = 1 0 6 )}$ & $\mathbf{( n = 7 0 )}$ & $\mathbf{( n = 7 8 )}$ & $\mathbf{( n = 7 9 )}$ & $\mathbf{( n = 1 0 5 )}$ \\
\hline REC & 23,867 & 6471 & 3479 & 44,928 & 20,669 & 6425 & 46,659 \\
\hline REV & 367,538 & 87,729 & 16,564 & 226,829 & 86,971 & 23,575 & 494,366 \\
\hline PPE & 165,446 & 21,117 & 29,666 & 227,127 & 33,327 & 39,087 & 567,275 \\
\hline TCA & 148,609 & 43,410 & 11,489 & 150,310 & 72,527 & 86,216 & 291,891 \\
\hline TA & 354,431 & 83,978 & 9221 & 47,261 & 156,671 & 147,991 & 807,815 \\
\hline TCL & 134,596 & 29,651 & 11,879 & 4638 & 45,697 & 50,086 & 218,419 \\
\hline STD & 30,174 & 6694 & 2686 & 28,375 & 20,731 & 17,875 \\
\hline CCE & 27,635 & 6928 & 2357 & 42,703 & 12,464 & 4349 \\
\hline D\&A & 15,693 & 1817 & 1880 & 5311 & 3951 & 65,049 \\
\hline
\end{tabular}

Table 3. Year wise summary statistics of all variables across all industries (in million rupees).

\begin{tabular}{cccccccccc}
\hline Year & REC & REV & TA & TCA & TCL & PPE & STD & CCE & D\&A \\
\hline FY 2011 & 9403 & 60,497 & 67,861 & 35,180 & 20,503 & 15,027 & 4926 & 6686 & 1581 \\
\hline FY 2012 & 12,915 & 79,605 & 87,874 & 48,624 & 24,918 & 18,029 & 5209 & 12,388 & 1992 \\
\hline FY 2013 & 15,865 & 99,225 & 107,688 & 60,074 & 31,295 & 21,521 & 7913 & 13,239 & 2404 \\
\hline FY 2014 & 20,003 & 122,465 & 130,917 & 77,218 & 37,635 & 25,465 & 9672 & 18,736 & 2920 \\
\hline FY 2015 & 21,407 & 130,520 & 139,462 & 82,217 & 41,615 & 28,401 & 9951 & 23,416 & 3360 \\
\hline FY 2016 & 25,515 & 141,393 & 163,776 & 91,700 & 42,885 & 30,629 & 12,362 & 23,092 & 3751 \\
\hline FY 2017 & 28,519 & 174,334 & 211,975 & 119,763 & 53,939 & 35,320 & 15,935 & 23,379 & 5132 \\
\hline FY 2018 & 32,593 & 183,034 & 232,767 & 125,112 & 58,552 & 38,095 & 16,058 & 22,782 & 5731 \\
\hline
\end{tabular}

The data are then winsorized at $1 \%$ and $99 \%$ levels. This winsorized data are used to compute the regression coefficients $\left(\alpha_{0}, \alpha_{1}, \alpha_{2}\right.$ and $\left.\alpha_{3}\right)$ using Equation (2) of the Modified Jones Model with the TACC values calculated from Equation (1). The regression results statistics and the coefficients of all the seven sectors are summarized in Table 4. 
Table 4. Summary statistics (mean and standard deviation) of the individual industry wise regression estimators of the Modified Jones model.

\begin{tabular}{cccccccc}
\hline Variables & Auto & FMCG & IT & Media & Metal & Pharma & Realty \\
\hline Constant $\left(\alpha_{0}\right)$ & 0.070 & 0.0426 & -0.086 & -0.068 & -0.017 & -0.18001 & -0.02423 \\
& $(0.128)$ & $(0.097)$ & $(0.336)$ & $(0.107)$ & $(0.213)$ & $(0.252)$ & $(0.112)$ \\
$1 / A_{t}-1\left(\alpha_{1}\right)$ & 1963.899 & -689.362 & -12.552 & 542.622 & -298.134 & 7273.424 & 878.3234 \\
$\left(\Delta R E V_{t}-\right.$ & $(1830.798)$ & $(2889.663)$ & $(1286.258)$ & $(274.088)$ & $(2388.114)$ & $(8366.806)$ & $(6108.166)$ \\
$\left.\Delta R E C_{t}\right) / A_{t}-1\left(\alpha_{2}\right)$ & -0.225 & -0.205 & 0.350 & -0.048 & 0.035 & 0.275784 & 0.092686 \\
$P P E_{t} / A_{t}-1\left(\alpha_{3}\right)$ & $(0.316)$ & $(0.439)$ & $(0.954)$ & $(0.346)$ & $(0.312)$ & $(1.342)$ & $(1.05816)$ \\
& -0.145 & -0.028 & 0.336 & -0.147 & -0.028 & 0.007341 & -0.06578 \\
\hline
\end{tabular}

After computing the regression coefficients for every sector-year combination, they are then substituted in Equation (3) for computing the non-discretionary accruals (NDACC). The Discretionary accruals is calculated by subtracting the non-discretionary accruals (NDACC: Equation (3)) from the Total accruals (TACC: Equation (2)). Table 5 shows descriptive statistics of the discretionary accruals for each industry separately over the period of study:

Table 5. Industry wise summary statistics (mean and standard deviation) of the discretionary accruals over the years.

\begin{tabular}{cccccccccccc}
\hline Category & Statistic & $\mathbf{2 0 1 1}$ & $\mathbf{2 0 1 2}$ & $\mathbf{2 0 1 3}$ & $\mathbf{2 0 1 4}$ & $\mathbf{2 0 1 5}$ & $\mathbf{2 0 1 6}$ & $\mathbf{2 0 1 7}$ & $\mathbf{2 0 1 8}$ & Average \\
\hline \multirow{2}{*}{ Automobile } & \multirow{2}{*}{ Median } & -0.022 & -0.016 & -0.013 & -0.006 & -0.030 & 0.002 & -0.024 & 0.000 & -0.014 \\
& & $(0.157)$ & $(0.080)$ & $(0.078)$ & $(0.041)$ & $(0.112)$ & $(0.101)$ & $(0.077)$ & $(0.121)$ & $(0.097)$ \\
\hline \multirow{2}{*}{ FMCG } & \multirow{2}{*}{ Median } & -0.010 & 0.067 & -0.004 & 0.005 & -0.051 & 0.035 & -0.020 & -0.003 & 0.003 \\
& & $(0.192)$ & $(0.182)$ & $(0.057)$ & $(0.159)$ & $(0.128)$ & $(0.190)$ & $(0.074)$ & $(0.069)$ & $(0.138)$ \\
\hline \multirow{2}{*}{ IT } & \multirow{2}{*}{ Median } & -0.015 & -0.007 & 0.010 & -0.007 & -0.009 & -0.067 & -0.025 & 0.005 & 0.005 \\
& & $(0.142)$ & $(0.115)$ & $(0.100)$ & $(0.070)$ & $(0.103)$ & $(0.147)$ & $(0.184)$ & $(0.061)$ & $(0.015)$ \\
\hline \multirow{2}{*}{ Media } & \multirow{2}{*}{ Median } & -0.016 & -0.003 & 0.019 & -0.046 & 0.047 & 0.031 & -0.022 & 0.008 & 0.003 \\
& & $(0.290)$ & $(0.166)$ & $(0.156)$ & $(0.172)$ & $(0.2290)$ & $(0.197)$ & $(0.126)$ & $(0.109)$ & $(0.180)$ \\
\hline \multirow{2}{*}{ Metal } & \multirow{2}{*}{ Median } & -0.070 & 0.080 & -0.007 & 0.006 & 0.004 & 0.014 & 0.014 & -0.012 & 0.010 \\
& & $(0.194)$ & $(0.205)$ & $(0.065)$ & $(0.034)$ & $(0.050)$ & $(0.101)$ & $(0.080)$ & $(0.029)$ & $(0.104)$ \\
\hline \multirow{2}{*}{ Pharma } & \multirow{2}{*}{ Median } & 0.008 & 0.004 & -0.005 & -0.003 & 0.023 & 0.017 & -0.020 & 0.013 & 0.011 \\
& & $(0.258)$ & $(0.129)$ & $(0.134)$ & $(0.087)$ & $(0.112)$ & $(0.126)$ & $(0.204)$ & $(0.077)$ & $(0.145)$ \\
\hline \multirow{2}{*}{ Realty } & \multirow{2}{*}{ Median } & 0.000 & 0.012 & -0.006 & 0.001 & -0.013 & 0.002 & 0.001 & -0.001 & -0.002 \\
& & $(0.207)$ & $(0.110)$ & $(0.069)$ & $(0.110)$ & $(0.073)$ & $(0.030)$ & $(0.058)$ & $(0.025)$ & $(0.097)$ \\
\hline
\end{tabular}

The Figure 1, below, shows the graphical view of the median values showing how the median discretionary accrual values have changed over the years for the seven sectors.

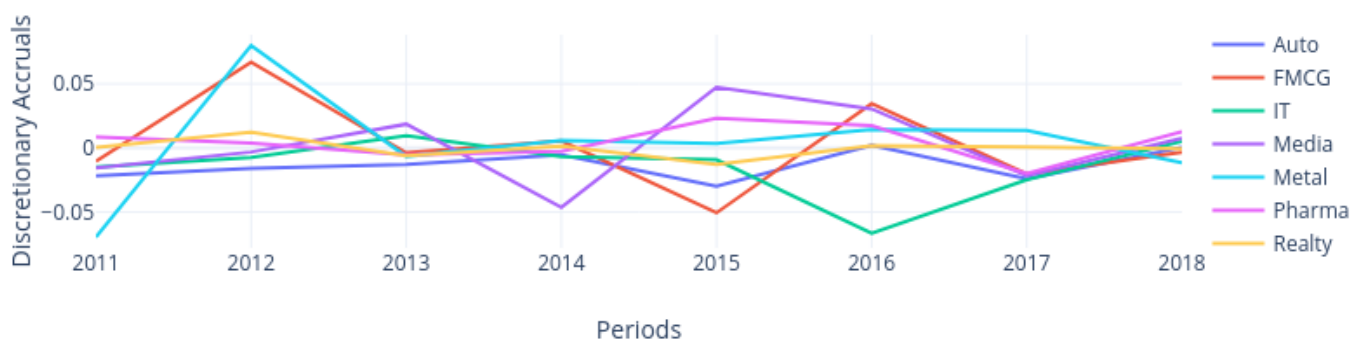

Figure 1. Discretionary Accruals over the years for the seven sectors.

From Table 5 and Figure 1, as given above, we can observe that the Media companies show high median values over most of the years taken for the study. These firms also exhibit very high standard deviations, indicating high discretionary accruals. Similar to 
media companies, realty companies also exhibited higher median values, although they did so with low standard deviations. Metal companies show high levels of positive and negative deviations during the period of study. They exhibit low standard deviations in six of the eight years of the study. This indicates that most of these firms have high levels of discretionary accruals. This is consistent with studies indicating that manufacturing firms will generally have high levels of discretionary accruals. Auto companies, on the other hand, showed high levels of negative discretionary accruals in six of the eight years of the study, with very low standard deviations indicating most of the automobile companies exhibited high negative discretionary accruals.

The Box Whisker Plot (Figure 1) shows the final output generated for the Modified Jones Model in Stata. The plot shows the trend in earnings management presumed to be undertaken by the management of all the companies in our sample over the last 8 years, thereby highlighting the firms (real names masked) which might have indulged in earnings management to a greater degree than the others in the group.

\section{Discussion}

The Companies Act (2013) requires that the financial statements of the firms are a "true and fair" view of the auditor's assessment. But it also allows for a considerable amount of judgement and flexibility in reporting, which can add to uncertainty and variations. This makes any quantitative assessment a relative evaluation between firms of similar nature. Based on the analysis of 89 sample firms across 8 years, Figure 1 reveals those firms which seem to have engaged in excessive levels of earnings management compared to other firms in the sample, for the period 2011 to 2018. The Box Whisker plot shows the outlier firms which might have engaged in excessive levels of earnings management compared to their peers. The inter-quartile range, indicated by the box in the plot, constitutes firms that had earnings management levels closer to the median value. This median value was close to zero for almost all years, across all industries.

From the pattern of the plot in Figures 1 and 2, it can be observed that firms seem to have engaged in high levels of earnings management, both positive and negative, in the financial years 2011 and 2012. This can be attributed to ineffective legislations and monitoring during that period. Indian regulations during this period allowed firms to use some earning management techniques, such as inventory valuation methods, front loading of expenses accrued, revenue and expense recognition techniques, transfer of goods inward or outward from an inflated or deflated market, and presenting unexpected gains or losses from long-term assets shown at cost to get desired outcomes without breaking the law. Though most common definitions of earnings management incorporate words like "purposeful" and "intentional", it is very difficult to establish a dominant managerial opportunism perspective in most cases, as it is difficult to operationalize directly using attributes of reported numbers. Dechow and Skinner (2000) differentiate between fraudulent accounting and acceptable ways managers can exercise discretion, whereas Healy and Wahlen (1999) argue that eliminating managers' discretion will be of disadvantage to investors. Hence, the present study is limited in scope to establishing the prevalence of earnings management though non-discretionary accruals and how this has been reduced after the implementation of the new Companies Act. The study however does not cover the specific elements of the new Companies Act, which has led to a reduction in earnings management.

Furthermore, we can observe that the size of the boxes decreases progressively over the study period from 2013 to 2018, with the exception of 2016, the year prior to the rollout of the Ind AS in convergence with IFRS. This indicates that firms were all lowering their discretionary accruals as the years progressed. This can be attributed to the stringent reporting standards introduced as part of the Companies Act 2013, the amendment to clause 49 of SEBI's listing agreement, the convergence of the Ind AS to the International Financial Reporting Standard (IFRS), which was made mandatory since the 2016 financial year for the firms included in the study, and the setting up of the National Financial 
Reporting Authority (NFRA) for enforcement of auditing standards and oversight of the auditors.

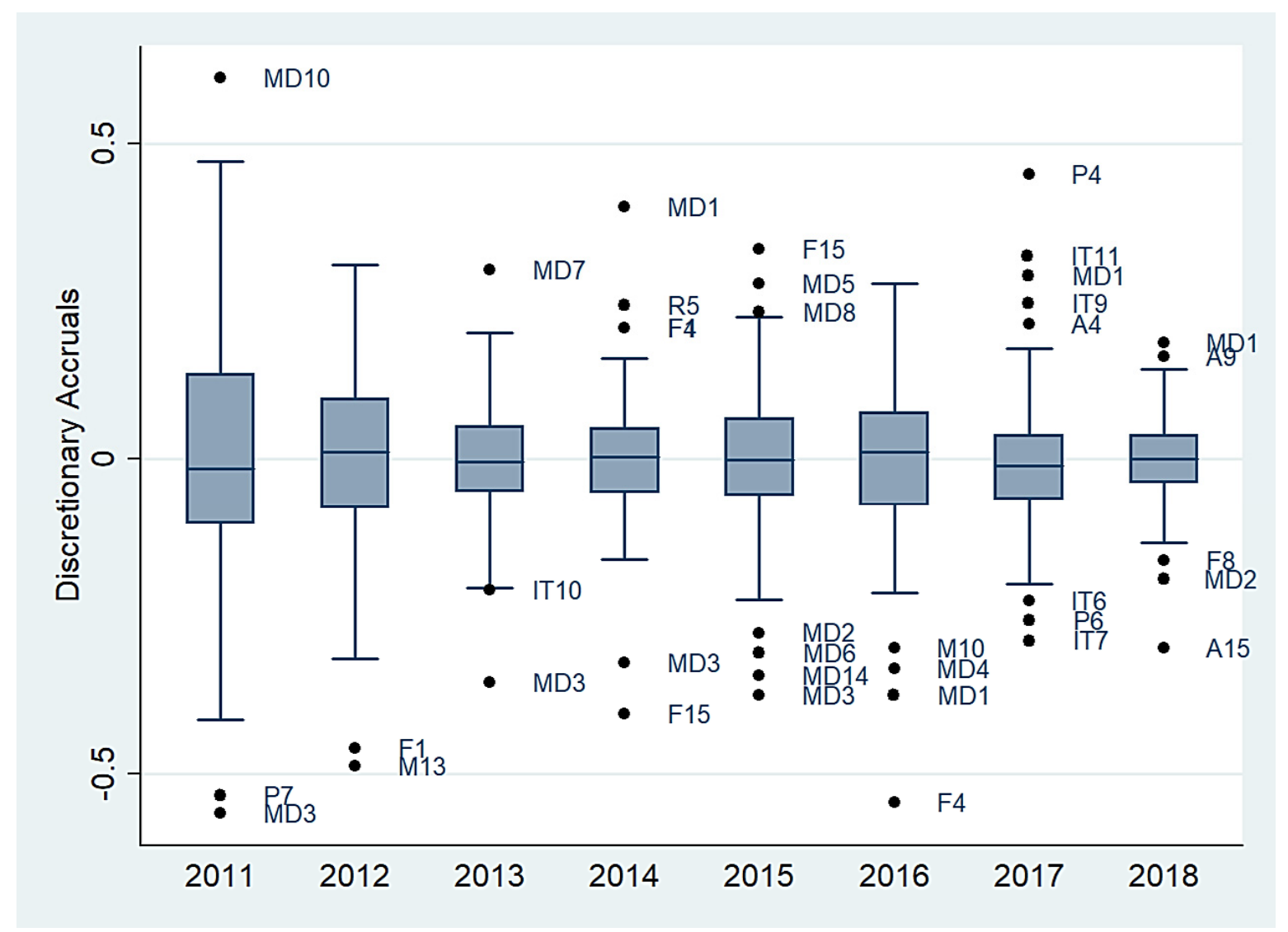

Figure 2. Box Whisker plot of discretionary accruals of all firms for the period 2011-2018. Note: The actual names of the companies are masked.

From the literature review, we know that the new Companies Act was introduced in 2013 and the improved Clause 49 was introduced in 2014. It is then fitting to claim that the positive effect of this piece of legislation is very clearly observable in Figure 2. The body of the Box Whisker plot significantly reduces in 2012 in anticipation of the legislation and reduces further in 2013 when the act was passed. Furthermore, we see that the EM figures have stabilized in the 2014-2016 period. Later, with the adoption of Ind AS in 2016 and the establishment of NFRA, we see that there is a further decline in EM levels, evident from the drop in the box and the whisker part of the plot in 2017 and 2018.

This shows that the large listed firms in India have become more cautions and that there is more trust and transparency in financial reporting after the introduction of the Companies Act 2013, the revision of Clause 49 of the listing agreement, the creation of the NFRA, the adoption of the Ind AS, and the convergence of this with IFRS.

Table 6 presents the masked names of the outlier firms in Figure 1 along with their respective industries. The table also indicates the firms with positive or negative earnings management separately for the period 2011 to 2018.

In the above table, we see that it is the media sector which seems to be continuously engaged in high levels of both positive ( 5 firms) and negative ( 7 firms) earnings management from 2011 onwards except in the year 2012. The FMCG sector companies are engaged in both positive ( 3 firms) and negative ( 4 firms) earnings management in alternative years. This shows that Media and FMCG have been the prominent industry groups engaged in EM over the years together, comprising about $20 \%$ of the total companies in the dataset. Recently, the Information Technology sector has also shown a spurt in earnings manage- 
ment. Apart from 2013, it is only in the year 2017 that some IT companies seem to have engaged in excessive EM, although there is the possibility of new names from the same sector(s) in the coming years. It is advisable to investigate the financial and operational patterns more closely and on a frequent basis to avoid such repeated occurrences from the same sector. An interesting phenomenon that can be noticed is that the firms in the services sector are the ones that frequently appear in the outlier groups. FMCG can be categorised under services industry as they are more focussed on trading, with their manufacturing almost completely outsourced. Some of the common earnings management practices, like inventory write-downs, warranty cost, sales return, etc., which were commonly adopted by manufacturing firms in the metals, pharmaceuticals, realty, and automobile industies have limited scope under the new law. This may be the reason that more services firms are engaged in excessive EM when compared to manufacturing firms.

Table 6. Firms showing excessing earnings management, tabulated by industry.

\begin{tabular}{|c|c|c|c|c|c|c|c|c|c|c|}
\hline & Industry & 2011 & 2012 & 2013 & 2014 & 2015 & 2016 & 2017 & 2018 & Count \\
\hline \multirow{6}{*}{$+\mathrm{VE}$} & Realty & & & & R5 & & & & & 1 \\
\hline & Pharmaceutical & & & & & & & P4 & & 1 \\
\hline & Automobile & & & & & & & A4 & A9 & 2 \\
\hline & IT & & & & & & & IT9, IT11 & & 2 \\
\hline & FMCG & & & & $\mathrm{F} 1, \mathrm{~F} 4$ & F15 & & & & 3 \\
\hline & Media & MD10 & & MD7 & MD1 & $\begin{array}{l}\text { MD5, } \\
\text { MD8 }\end{array}$ & & MD1 & MD1 & 5 \\
\hline \multirow{6}{*}{$-\mathrm{VE}$} & Media & MD3 & & MD3 & MD3 & $\begin{array}{l}\text { MD2, } \\
\text { MD3, } \\
\text { MD6, } \\
\text { MD14 }\end{array}$ & $\begin{array}{l}\text { MD1, } \\
\text { MD4 }\end{array}$ & & MD2 & 7 \\
\hline & FMCG & & $\mathrm{F} 1$ & & F15 & & $\mathrm{F} 4$ & & F8 & 4 \\
\hline & IT & & & IT10 & & & & IT6, IT7 & & 3 \\
\hline & Automobile & & & & & & & & A15 & 1 \\
\hline & Pharmaceutical & P7 & & & & & & P6 & & 2 \\
\hline & Metal & & M13 & & & & M10 & & & 2 \\
\hline
\end{tabular}

Manufacturing and trading companies have large inventories and equally large receivables. In the past, this may have made it relatively easier for earnings management through traditional methods like inventory valuation and bad debt provisions. Likewise, financial figures are relatively more volatile in some industries (e.g., services) than in other industries and thus act as a good camouflage to earnings management activities. However, it was hard to carry out post 2013 when the new Companies Act was rolled out and even more difficult after the mandatory implementation of Ind AS by large listed firms in 2016. The levels of control and collaboration between board and managers, power balance, and performance linked executive compensation can all influence earning management in firms. The new Companies Act, which was a comprehensive overhaul of the 1956 law, brought significant improvements in governance, compliance, enforcement, disclosures, the auditor's role and responsibilities, valuation, class action suits, and mergers and acquisitions; these factors have significantly reduced discretionary accruals used as a proxy to earnings management. Furthermore, the new law has also restricted the number of directorships that could be held by an individual and has mandated the need for the directors to mandatorily attend at least one board meeting in a year. The new law also restricts auditors to a maximum tenure of 5 years and prevents them from offering many specialized services directly or indirectly to the companies they audit. Beattie et al. (2014) show that the level of engagement between audit committees, ethics committees, CFOs, and audit partners also 
have an influence on earning management. This shows that once there is better regulation, regulation enforcement, and mandatory board diversity, companies improve their governance standards. The set of accepted accounting procedures has become more constricted, reducing managers' discretion and flexibility in the choice of accounting principles and ability to manage earnings.

\section{Conclusions}

In general, earnings management is not always bad (Parfet 2000), but the process becomes illegal and unethical if the intention is to hide real operating performance by creating misleading accounting entries or expanding estimates beyond a reasonable level. Such practices downgrade the reputation of the firm in the eyes of the public, making the company look non-viable for investing and unattractive to investors. In order to survive and grow in today's competitive environment, companies often engage in certain manipulative activities to achieve their short-term objectives, thus sacrificing long-term benefits. The growth of both the firm and economy will thus be affected in the long run. Thus, it is imperative that firms abide by norms, standards, beliefs, and values and thus win the trust of society.

We can also observe that there is an overall decline in the levels of EM, indicating a rise in the legitimacy of corporate reporting. This can be attributed to the adoption of strict accounting standards, such as Ind AS and IFRS, along with stricter regulations. A positive trend can be seen in the reporting standards of the corporations, primarily due to the effective implementation of improved standards and the establishment of monitoring agencies to track violations. These initiatives ensure a well-regulated level playing environment for all firms, leaving no scope for deviation. From the study, we can deduce that strict implementation and adherence to the corporate governance mandates benefit not only the firms themselves, but also their peers, the market, and the economy as a whole. This benefit to the economy will positively affect the stakeholders of the firm, accelerating growth and the profitability of the firm.

We are able to draw the broad conclusion that earnings management is prevalent in the services and manufacturing sector, although to different degrees. The study was also able to show that better corporate governance ushered in through improved regulations over the study period though the Companies Act of 2013, revision of clause 49 of SEBI's listing regulation, and the convergence of Indian accounting standards with IFRS through the phased adoption of IndAS has had significant impact on minimising earnings management. Future studies can explore the situation prevailing in individual industry groups and whether the nature of the business is a factor for higher levels of earnings management practices in services firms. Further studies could involve a broad-based sample to validate the findings of this study by formulating hypotheses and testing for impact of specific factors towards EM practices or towards improved corporate governance practices. This study can be expanded into a multi-nation study to compare the levels of earnings management in developing and developed economies. It will help to understand the effect of regulations and enforcement effectiveness on the legitimacy of reporting, accounting, and auditing of financial statements. The outcome will increase investor participation and confidence in the markets.

Author Contributions: Conceptualization, J.J.T. and R.J.N.; methodology, J.J.T.; software, J.J.T.; validation, J.J.T., R.J.N. and V.V.; formal analysis, J.J.T.; writing-original draft preparation, J.J.T., R.J.N. and V.V.; writing-review and editing, J.J.T. and V.V.; visualization, J.J.T.; supervision, R.J.N. and V.V. All authors have read and agreed to the published version of the manuscript.

Funding: This study is funded by the Fundamental Research Grant Scheme, Ministry of Higher Education Malaysia FRGS/1/2020/SS0/MMU/02/7 (MMUE/190256) Project ID: 18086. The data presented, statements made and views expressed are solely the responsibility of the authors.

Institutional Review Board Statement: Not applicable.

Informed Consent Statement: Not applicable. 
Data Availability Statement: The data used for analysis can be accessed from: https://github.com/ vjvictor/supplementary_data accessed on: 15 September 2021.

Conflicts of Interest: The authors declare no conflict of interest.

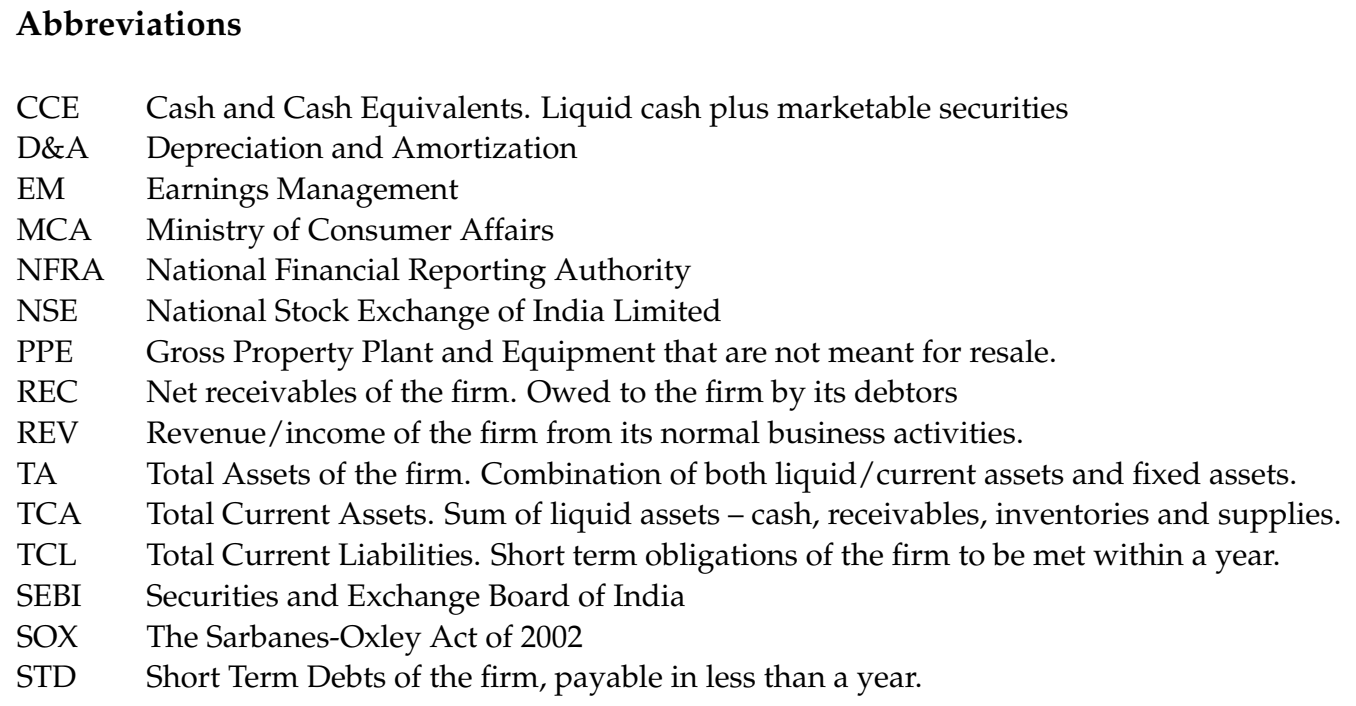

\section{Appendix A}

Notations

$\begin{array}{ll}\text { Variables and functions } \\ \alpha_{1}, \alpha_{2} \text { and } \alpha_{3} & \text { Estimated parameters of the coefficients of the Modified Jones model. } \\ \Delta C A_{t} & \text { Change in current assets in year } t, \\ \Delta C a s h_{t} & \text { Change in cash and cash equivalents in year } t, \\ \Delta C L_{t} & \text { Change in current liabilities in year } t, \\ \Delta D C L_{t} & \text { Change in short term debt included in current liabilities in year } t, \\ \triangle R E V_{t} & \text { Revenues is year } t \text { less revenues in year } t-1, \\ \triangle R E C_{t} & \text { Net receivables in year } t \text { less net receivables in year } t-1, \\ D E P_{t} & \text { Depreciation and amortization expense in year } t . \\ N D A C C_{t} & \text { Non-discretionary accruals divided by total assets in year } t-1 \\ P P E_{t} & \text { Gross property plant and Equipment in year } t \\ T A C C_{t} & \text { Total Accruals in year } t\end{array}$

\section{References}

Baik, Yoon-Suk, and Jaywon Lee. 2007. Earnings Management Dynamics and Deregulation: Case of the US Airline Industry (Working Papers). Kaist Business School Working Paper No. 2007-008. New York: SSRN. [CrossRef]

Beattie, Vivien, Stella Fearnley, and Hines Tony. 2014. Boundary spanning and gatekeeping roles of UK audit committees. Accounting and Business Research 44: 315-43. [CrossRef]

Brickey, Kathleen F. 2003. From Enron to WorldCom and Beyond: Life and Crime After Sarbanes-Oxley. Washington University Law Review 81: 357-401. [CrossRef]

Burgstahler, David, and Ilia Dichev. 1997. Earnings management to avoid earnings decreases and losses. Journal of Accounting and Economics 24: 99-126. [CrossRef]

Byun, Sanghyuk, and Kristin Roland-Luttecke. 2014. Meeting-or-Beating, Earnings Management, and Investor Sensitivity after the Scandals. Accounting Horizons 28: 847-67. [CrossRef]

Callao, Susana, Riccardo Cimini, and José Ignacio Jarne. 2016. Value relevance of accounting figures in presence of earnings management. Are enforcement and ownership diffusion really enough? Journal of Business Economics and Management 17: 1286-99. [CrossRef]

Carcello, Joseph V., and Albert L. Nagy. 2004. Audit Firm Tenure and Fraudulent Financial Reporting. AUDITING: A Journal of Practice E Theory 23: 55-69.

Cheng, Qiang, and Terry Warfield. 2005. Equity Incentives and Earnings Management. The Accounting Review 80: 441-76. [CrossRef]

Cohen, Daniel A., and Paul Zarowin. 2008. Real and Accrual-based Earnings Management in the Pre and Post Sarbanes Oxley Periods. The Accounting Review 83: 757-87. [CrossRef] 
Cohen, Jeffrey R., Udi Hoitash, Ganesh Krishnamoorthy, and Arnold M. Wright. 2014. The Effect of Audit Committee Industry Expertise on Monitoring the Financial Reporting Process. The Accounting Review 89: 243-73. [CrossRef]

Dayanandan, Ajit, and Jaspreet Kaur Sra. 2018. Accrual management and expected stock returns in India. Journal of Accounting in Emerging Economies 8: 426-41. [CrossRef]

Dayanandan, Ajit, Han Donker, Mike Ivanof, and Gökhan Karahan. 2016. IFRS and accounting quality: Legal origin, regional, and disclosure impacts. International Journal of Accounting \& Information Management 24: 296-316. [CrossRef]

DeAngelo, Linda. 1988. Discussion of evidence of earnings management from the provision for bad debts. Journal of Accounting Research 26: 32-40. [CrossRef]

Dechow, Patricia M., and Douglas J. Skinner. 2000. Earnings Management: Reconciling the Views of Accounting Academics, Practitioners, and Regulators. Accounting Horizons 14: 235-50. [CrossRef]

Dechow, Patricia M., Richard G. Sloan, and Amy P. Sweeney. 1995. Detecting Earnings Management. The Accounting Review 70: 193-225.

Dhaoui, Abderrazak. 2008. R\&D diversification in MNCs: Between earnings management and shareholders increasing wealth. Journal of Business Economics and Management 9: 199-205.

Di Meo, Fabrizio, Juan Manuel García Lara, and Jordi A. Surroca. 2017. Managerial entrenchment and earnings management. Journal of Accounting and Public Policy 36: 399-414. [CrossRef]

Dichev, Ilia, John Graham, Campbell R. Harvey, and Shiva Rajgopal. 2016. The Misrepresentation of Earnings. Financial Analysts Journal 71: 22-35. [CrossRef]

Doukakis, Leonidas C. 2014. The effect of mandatory IFRS adoption on real and accrual-based earnings management activities. Journal of Accounting and Public Policy 33: 551-72. [CrossRef]

Du, Qianqian, and Rui Shen. 2018. Peer performance and earnings management. Journal of Banking E Finance 89: $125-37$.

Epps, Ruth W., and Tariq Hassaneen Ismail. 2009. Board of Directors' Governance Challenges and Earnings Management. Journal of Accounting E Organizational Change 5: 390-416. [CrossRef]

Fisher, Timothy C. G., Ilanit Gavious, and Jocelyn Martel. 2016. Earnings Management, Chapter 11. Emergence and Firm Value. SSRN. Available online: https:/ / ssrn.com/abstract=2786587 (accessed on 7 September 2021).

Goel, Sandeep. 2018. Earnings management in corporate enterprises in India: A test for multi-nationality, reputation and related variables. International Journal of Emerging Markets 13: 1820-34. [CrossRef]

González, Jesus Sáenz, and Emma García-Meca. 2014. Does Corporate Governance Influence Earnings Management in Latin American Markets? Journal of Business Ethics 121: 419-40. [CrossRef]

Graham, John R., Campbell R. Harvey, and Shiva Rajgopal. 2005. The economic implications of corporate financial reporting. Journal of Accounting and Economics 40: 3-73. [CrossRef]

Healy, Paul M. 1985. The effect of bonus schemes on accounting decisions. Journal of Accounting and Economics 7: 85-107. [CrossRef]

Healy, Paul M., and James M. Wahlen. 1999. A Review of the Earnings Management Literature and Its Implications for Standard Setting. Accounting Horizons 13: 365-83. [CrossRef]

International Monetary Fund. 2013. Report Country Report No. 13/226. India: Financial Sector Assessment Program-Detailed Assessments Report on IOSCO Objectives and Principles of Securities Regulation. Available online: https://www.imf.org/ external/pubs/ft/scr/2013/cr13266.pdf (accessed on 15 September 2021).

Ipino, Elisabetta, and Antonio Parbonetti. 2016. Mandatory IFRS adoption: The trade-off between accrual-based and real earnings management. Accounting and Business Research 47: 91-121. [CrossRef]

Jeanjean, Thomas, and Hervé Stolowy. 2008. Do accounting standards matter? An exploratory analysis of earnings management before and after IFRS adoption. Journal of Accounting and Public Policy 27: 480-94. [CrossRef]

Jones, Jennifer J. 1991. Earnings Management during Import Relief Investigations. Journal of Accounting Research 29: 193-99. [CrossRef]

Kang, Sun-A., and Yong-Shik Kim. 2012. Effect of corporate governance on real activity-based earnings management: Evidence from Korea. Journal of Business Economics and Management 13: 29-52. [CrossRef]

Kedia, Simi, and Thomas Philippon. 2007. The Economics of Fraudulent Accounting. The Review of Financial Studies 22: 2169-99. [CrossRef]

Khan, Muhammad Kaleem, Ying He, Ahmad Kaleem, Umair Akram, and Zahid Hussain. 2018. Remedial role of financial development in corporate investment amid financing constraints and agency costs. Journal of Business Economics and Management 19: 176-91. [CrossRef]

Klein, April. 2002. Audit committee, board of director characteristics, and earnings management. Journal of Accounting and Economics 33: 375-400. [CrossRef]

Lambert, Caroline, and Samuel Sponem. 2005. Corporate governance and profit manipulation: A French field study. Critical Perspectives on Accounting 16: 717-48. [CrossRef]

Larcker, David F., Scott A. Richardson, and I'rem Tuna. 2007. Corporate Governance, Accounting Outcomes and Organizational Outcomes. The Accounting Review 82: 963-1008. [CrossRef]

Leuz, Christian, Dhananjay Nanda, and Peter D. Wysocki. 2003. Earnings management and investor protection: An international comparison. Journal of Financial Economics 69: 505-27. [CrossRef]

Lin, Jerry W., and Mark I. Hwang. 2010. Audit Quality, Corporate Governance, and Earnings Management: A Meta-Analysis. International Journal of Auditing 14: 57-77. [CrossRef] 
Liu, Qiao, and Zhou Lu. 2007. Corporate governance and earnings management in the Chinese listed companies: A tunneling perspective. Journal of Corporate Finance 13: 881-906. [CrossRef]

López, M. Victoria, Arminda Garcia, and Lazaro Rodriguez. 2007. Sustainable Development and Corporate Performance: A Study Based on the Dow Jones Sustainability Index. Journal of Business Ethics 75: 285-300. [CrossRef]

Moradi, Mahdi, Mahdi Salehi, and Mohammad Zamanirad. 2015. Analysis of incentive effects of managers' bonuses on real activities manipulation relevant to future operating performance. Management Decision 53: 432-50. [CrossRef]

Nathan, Robert Jeyakumar, Chin Xin Yi, Eva H. Görgényi, Vijay Victor, G. Gonda, and M. Fekete Farkas. 2019. Impact of Knowledge and Innovation Management to Firm Financial and Non-Financial Performance. Vadyba Journal of Management 35: 71-81.

Nosratabadi, Saeed, Gergo Pinter, Amir Mosavi, and Sandor Semperger. 2020. Sustainable banking; evaluation of the European business models. Sustainability 12: 2314. [CrossRef]

Parfet, William U. 2000. Accounting Subjectivity and Earnings Management: A Preparer Perspective. Accounting Horizons 14: 481-88. [CrossRef]

Park, KoEun. 2019. Does peer firm executive compensation affect earnings management? Managerial Finance 45: 54-71. [CrossRef]

Popescu, Cristina Raluca Gh, and Gheorghe N. Popescu. 2019. An Exploratory Study Based on a Questionnaire Concerning Green and Sustainable Finance, Corporate Social Responsibility, and Performance: Evidence from the Romanian Business Environment. Journal of Risk and Financial Management 12: 162. [CrossRef]

Punniyamoorthy, Murugesan, and Jose Joy Thoppan. 2012. ANN-GA based model for stock market surveillance. Journal of Financial Crime 20: 52-66. [CrossRef]

Rahman, Rashid, and Fairuzana Ali. 2006. Board, Audit committee, Culture and Earnings Management: Malaysian Evidence. Managerial Auditing Journal 21: 783-804. [CrossRef]

Rangan, Srinivasan. 1998. Earnings Management and the Performance of Seasoned Equity Offerings. Journal of Financial Economics 50: 101-22. [CrossRef]

Ronen, Joshua, and Varda Yaari. 2008. Earnings Management: Emerging Insights in Theory, Practice, and Research. New York: Springer US.

Rudra, Titas, and CA Dipanjan Bhattacharjee. 2012. Does IFRS Influence Earnings Management? Journal of Management Research 4. [CrossRef]

Sarkar, Jayati, Subrata Sarkar, and Kaustav Sen. 2008. Board of Directors and Opportunistic Earnings Management: Evidence from India. Journal of Accounting. Auditing \& Finance 23: 517-51. [CrossRef]

Shen, Chung-Hua, and Hsiang-Lin Chih. 2005. Investor Protection, Prospect Theory, and Earnings Management: An International Comparison of the Banking Industry. Journal of Banking and Finance 29: 2675-97. [CrossRef]

Shen, Chung-Hua, and Hsiang-Lin Chih. 2007. Earnings Management and Corporate Governance in Asia's Emerging Markets. Corporate Governance: An International Review 15: 999-1021. [CrossRef]

Škare, Marinko, and Tea Hasić. 2016. Corporate governance, firm performance, and economic growth—Theoretical analysis. Journal of Business Economics and Management 17: 35-51. [CrossRef]

Srivastava, Varnita, Niladri Das, and Jamini Kanta Pattanayak. 2018. Corporate governance: Mapping the change. International Journal of Law and Management 60: 19-33. [CrossRef]

Steurer, Reinhard, Markus E. Langer, Astrid Konrad, and André Martinuzzi. 2005. Corporations, stakeholders and sustainable development: A theoretical exploration of business-society relations. Journal of Business Ethics 61: 263-81. [CrossRef]

Stewart, Bennett. 2006. The Real Reasons Enron Failed. Journal of Applied Corporate Finance 18: 116-19. [CrossRef]

Suryani, Arna, K. Pirzada, and Mufidah. 2018. Analysis of opportunistic behavior of management to company performance. Polish Journal of Management Studies 18: 379-88. [CrossRef]

Teoh, Siew Hong, Ivo Welch, and Tak Jun Wong. 1998. Earnings management and the underperformance of seasoned equity offerings. Journal of Financial Economics 50: 63-99. [CrossRef]

Teoh, Siew Hong, Ivo Welch, and T. J. Wong. 2002. Earnings Management and the Long-Run Market Performance of Initial Public Offerings. The Journal of Finance 53: 1935-74. [CrossRef]

Van Tendeloo, Brenda, and Ann Vanstraelen. 2005. Earnings Management under German GAAP versus IFRS. European Accounting Review 14: 155-80. [CrossRef]

Van Tendeloo, Brenda, and Ann Vanstraelen. 2008. Earnings management and audit quality in Europe: Evidence from the private client segment market. European accounting Review 17: 447-69. [CrossRef]

Young, Steven. 1999. Systematic Measurement Error in the Estimation of Discretionary Accruals: An Evaluation of Alternative Modelling Procedures. Journal of Business Finance and Accounting 26: 833-62. [CrossRef]

Zéman, Zoltán, and Cs Lentner. 2018. The changing role of going concern assumption supporting management decisions after financial crisis. Polish Journal of Management Studies 18: 428-41. [CrossRef] 